DOI: https://doi.org/10.34069/AI/2021.44.08.3

How to Cite:

Danylchuk, L., Yosyfovych, D., Kohut, Y., Todortseva, Y., \& Kozyra, P. (2021). New challenges in the problem of combating human trafficking in Ukraine. Amazonia Investiga, 10(44), 28-37. https://doi.org/10.34069/AI/2021.44.08.3

\title{
New challenges in the problem of combating human trafficking in Ukraine
}

\section{НОВІ ВИКЛИКИ У ПРОБЛЕМІ ПРОТИДІЇ ТОРГІВЛІ ЛЮДЬМИ В УКРАЇНІ}

Received: July 10, 2021

\section{Abstract}

The article presents the author's results of theoretical and empirical analyzes of challenges in combating human trafficking in Ukraine. Theoretical analysis showed that human trafficking is an interdisciplinary problem and is represented by a number of studies by scientists in various scientific fields in the domestic and foreign scientific space. It has been established that currently there is no research on new challenges in combating human trafficking in Ukraine. Empirical analysis of new challenges in combating trafficking in human beings in Ukraine was carried out through the implementation of a polygon study and interpretation of the results. The obtained data outline new challenges in the problem of combating human trafficking in Ukraine, such as: use for selfish purposes, forced donation, trade in biological/genetic material, reproductive programs/surrogacy. The results suggest that the new challenges in combating human trafficking
Accepted: August 25, 2021

Written by:

Larysa Danylchuk ${ }^{11}$

https://orcid.org/0000-0002-7156-5071

Web of Science Researcher ID AAR-2259-2021

Danylo Yosyfovych ${ }^{12}$

https://orcid.org/0000-0001-5510-9781

Yaroslav Kohut ${ }^{13}$

https://orcid.org/0000-0001-8027-0171

Yuliia Todortseva ${ }^{14}$

https://orcid.org/0000-0002-4708-581X

Web of Science Researcher ID AAR-2606-2021

Petro Kozyra ${ }^{15}$

https://orcid.org/0000-0002-3046-9841

\section{Анотація}

У статті представлені результати теоретичного та емпіричного аналізу викликів боротьби 3 торгівлею людьми в Україні. Теоретичний аналіз показав, що торгівля людьми $\epsilon$ міждисциплінарною проблемою i представлена низкою досліджень вчених у різних наукових галузях вітчизняного та зарубіжного наукового простору. Встановлено, що на даний час в Україні немає досліджень щодо нових викликів у боротьбі 3 торгівлею людьми. Емпіричний аналіз нових викликів у боротьбі 3 торгівлею людьми в Україні був проведений шляхом польового дослідження та інтерпретації результатів. Отримані дані окреслюють нові проблеми у боротьбі 3 торгівлею людьми в Україні, такі як: використання в корисливих цілях, примусове донорство, торгівля біологічним/генетичним матеріалом, репродуктивні програми/сурогатне материнство. Результати

\footnotetext{
${ }^{11}$ Doctor of Pedagogical Sciences, Associate Professor, Professor of Social Work and Pedagogics Department, Khmelnytsky National University, Khmelnitsky, Ukraine.

${ }^{12}$ Candidate of Law, Associate Professor, Deputy Dissertator of the Institute for Training Specialists for National Police Units, Lviv State University of Internal Affairs, Lviv, Ukraine.

${ }^{13}$ Candidate of Juridical Sciences, Associate Professor, Head of Department of Social and Humanitarian Training, Lviv State University of Internal Affairs, Lviv, Ukraine.

${ }^{14}$ Candidate of Pedagogical Sciences, Associate Professor of Psychology and Social Work Department, Odessa Polytechnic State University, Odessa, Ukraine.

${ }^{15}$ Candidate of Psychological Sciences, Associate Professor of Practical Psychology Department, Institute of Management, Psychology and Security, Lviv state university of internal affairs, Lviv, Ukraine.
} 


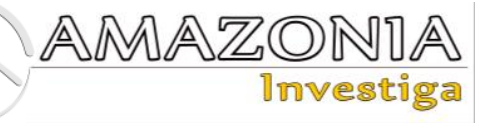

in Ukraine are a real platform for transnational crime. It was stated that such circumstances require strengthening of international cooperation in combating transnational human trafficking, legal regulation and improving the domestic legal framework with systematic and full informing of Ukrainian people about consequences and new challenges in combating human trafficking.

Keywords: crime, legal regulation, forced donation, human trafficking, reproductive programs, surrogacy.

свідчать про те, що нові виклики у боротьбі з торгівлею людьми в Україні є справжньою платформою для транснаціональної злочинності. Зазначено, що такі обставини потребують посилення міжнародної співпраці у боротьбі 3 транснаціональною торгівлею людьми, правового регулювання та вдосконалення вітчизняної правової бази із систематичним та повним інформуванням українського населення про наслідки та нові виклики у боротьбі з торгівлею людьми.

Ключові слова: злочинність, правове регулювання, примусове донорство, торгівля людьми, репродуктивні програми, сурогатне материнство.

\section{Introduction}

Globalization has not solved the problem of transnational crime, among which trafficking in human beings, according to the United Nations Office on Drugs and Crime, ranks third in terms of income, after arms and drug trafficking. Although human trafficking has deep historical roots, its relevance in the 21 st century is confirmed by the fact that virtually all countries in the world, regardless of their political system or economic stability, are affected by illegal trade flows and millions of people become "human commodities" every year. Unfortunately, such world trends also take place in Ukraine. Official statistics on human trafficking in Ukraine exist and show more than 230,000 people between 1991 and 2020, but experts and scientists say that the actual number of victims is several times higher and cannot be established.

The world community recognizes trafficking in human beings as a violation of fundamental human rights and freedoms, a violation of the principle of the equal dignity of all human beings and the rule of law stated in UN declarative documents. Ukraine has also joined the international fight against this negative phenomenon at the legislative and professional and practical levels, ratifying international conventions, protocols and resolutions. Also adopting its own laws and regulations, including the Laws of Ukraine: "On Ratification of the United Nations Convention against Transnational Organized Crime and the Protocols thereto" (Law No. 1433-IV, 2004), "On Combating Trafficking in Human Beings" (Law No. 3739-VI, 2012) and the Resolutions of the Cabinet of Ministers of Ukraine: "On the National Coordinator on Combating Trafficking Human Beings” (Resolution No. 29, 2012), “On

Approval of the Regulations on the Establishment and Operation of the Unified State Register of Crimes of Trafficking in Human Beings" (Resolution No. 303, 2012), “On Approval of the Procedure for Establishing the Status of a Person Who Has Suffered from Human Trafficking" (Resolution No. 417, 2012), "On Approval of the Procedure for Interaction of Entities Carrying Out Measures in the Field of Combating Trafficking in Human Beings" (Resolution No. 783, 2012).

However, socio-political changes in Ukraine in 2013-2014 and the military conflict in eastern Ukraine in 2014-2021 led to weaknesses in the further implementation of domestic antitrafficking policy, including: the financial crisis; increasing unemployment and migrant workers; incomplete reforms of the legal system; administrative reform; increase in social problems, etc.; insufficient interaction between the authorities and the public in the problem of human trafficking and, as a consequence, the emergence of new challenges.

The strategic importance of the issue of combating human trafficking and the above circumstances determine the problem of new challenges in combating trafficking in human beings in Ukraine to be considered relevant in time and one that requires special research.

The purpose of the article is a theoretical analysis of the state of development of the problem of human trafficking in the Ukrainian and foreign scientific space and an empirical analysis of new challenges in combating human trafficking in Ukraine. In accordance with the stated goal, the tasks were defined: 1 . Theoretically analyze the 
state of development of the problem of combating trafficking in human beings in Ukraine in the domestic and foreign scientific space. 2. Empirically analyze new challenges in combating human trafficking in Ukraine. 3. Based on the obtained experimental data to formulate generalized conclusions and prospects for further research on new challenges in combating human trafficking in Ukraine.

\section{Methodology}

To achieve the goal and defined tasks and to obtain empirical research data, the following methods were used:

1) theoretical methods: analysis, systematization, comparison, generalization of scientific papers on human trafficking in Ukraine and abroad;

2) empirical methods: questionnaires, groupings, surveys, detailing - for the implementation of polygon research; methods of quantitative and qualitative analysis of experimental data, graphical method of statistical data processing (construction of tables), comparative method - for processing and interpretation of the obtained results.

\section{Theoretical framework or Literature Review}

The problem of human trafficking is interdisciplinary and is represented in the Ukrainian scientific space by research in various fields, and therefore, scientists try to study it from the standpoint of the science they represent. The analysis of theoretical and applied aspects in the field of combating human trafficking is covered in the works of Sviatun (2005); Ahtyrska, Yudenko, Lavrovska, (2006); Punda (2013); Lukach (2016); Turok (2016); Mruchkovska, Pakhomiuk, Kocherga (2017). Protection of the rights and interests of victims of human trafficking: Pashchenko (2020). Criminal liability for human trafficking: Lyzohub (2003); Pidhorodynskyi (2005). Investigation of crimes related to human trafficking Kuts, Orlean (2007); Horbasenko (2013); Kravchenko (2020). Social prevention of human trafficking: Levchenko, Trubavina (2007); Danylchuk (2018). Combating and prevention of child trafficking: Kovalchuk (2010); Shcherbakovska (2012); Lesko (2019); Faryma (2021). Mechanisms of public administration in the field of combating human trafficking: Zhukovska (2017). Trafficking in women: Dzhezhyk (2021); Punda (2014) and others. It should be noted that a number of studies on human trafficking are empirical.

At the same time, foreign scholars (Hodge (2008); Hopper (2017); Kidane (2011); McClain, Garrity (2011); Panigabutra-Roberts (2012); Shinkaruk, Khaydarzoda, (2016); Yakushko, (2009) and others) also presented their research on the problem of human trafficking. However, we have not found any special research on the problem of human trafficking in Ukraine. In the public sphere, there are a number of studies edited by the UN, OSCE, IOM, ECPAT, the British Council and other international and nongovernmental organizations, which are mainly methodological and statistical or comparative and legal in nature "Communication from the Commission to the European Parliament, the Council, the European Economic and Social Committee and the Committee of the Regions. The EU Strategy towards the Eradication of Trafficking in Human Beings 2012-2016" (European Commission, 2012); "Combating Trafficking in Persons: A Handbook for Parliamentarians" (UNODC, 2009); "ILO Action Against Trafficking in Human Beings" (ILO, 2008) and others.

An analysis of scientific sources on trafficking in human beings has shown that, despite a number of publications, new challenges in combating trafficking in human beings remain insufficiently covered and substantiated.

Ukrainian law, like that of most countries, recognizes trafficking as a crime. According to the Law of Ukraine "On Amendments to Article 149 of the Criminal Code of Ukraine on Alignment with International Standards" (Law No. 2539-VIII, 2018) in Article 149 part 1 it is stated: "Trafficking in human beings, as well as recruitment, transfer, concealment, transfer or receipt of a person committed for the purpose of exploitation, using coercion, abduction, deception, blackmail, material or other dependence of the victim, his vulnerable condition or bribery of a third person who controls the victim to obtain consent for his exploitation - shall be punishable by imprisonment for a term of three to eight years".

Based on the concept of "human trafficking" from the above article, Ukrainian scientists identify and study the problem from different positions and approaches, namely:

from globalization: as a negative consequence of globalization; 


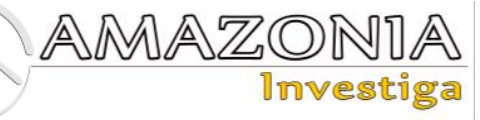

from the national approach: as a threat to the national security of Ukraine;

from the legal approach: as a violation of human rights - a crime punishable under the current legislation of Ukraine;

from the political approach: as a result of sociopolitical changes and political crises;

from the economic approach: as consequences of economic crises - unemployment and lack of money and reduction of financing of social programs;

from the demographic approach: as the imperfection of demographic and migration policy of Ukraine;

from the social approach: as a violation of moral and social norms of society;

from the socio-pedagogical approach: as a result of the lack of established life competencies based on respect for human rights;

from the preventive approach: as the understanding of responsibility for one's own life and one's own actions, including the crime committed (in the context of mediation or involvement in the situation of human trafficking);

from the psychological and medical approach: as a need to rehabilitate and protect victims from trafficking.

We intentionally do not detail existing developments on definitions, factors, legal and financial aspects of trafficking, which are sufficiently substantiated and presented elsewhere. At present, in the Ukrainian scientific discourse, the distinction/identification of the concepts of "human trafficking" and "slavery" remains controversial. The issues of ways to get into the situation of human trafficking and responsibility for human trafficking are debatable. The attitude of Ukrainians themselves towards victims of human trafficking and the confidentiality of information about them, etc. are ambiguous.

It should be noted that the Ukrainian media are actively involved in informing the public about the problem of human trafficking. The most discussed are sexual exploitation and forced labour. At the same time, we believe that there are new challenges in the problem of combating human trafficking, which are due to the situation in Ukraine.

\section{Research procedure}

In order to clarify the attitude of Ukrainians to the problem of human trafficking and new challenges to it, we conducted a polygon study, which covered the following regions of Ukraine:
Khmelnytskyi, Lviv, Ivano-Frankivsk, Ternopil, Vinnytsia, Odesa, Kyiv, Zaporizhzhia, Kharkiv, Zhytomyr, Volyn, Poltava, Kherson. The study was conducted in February-April 2021. In general, the polygon study involved the development of experimental material, data collection, preparation of collected data for processing, their analysis, mathematical processing, formulation of conclusions, as well as determining the prospects for further scientific research

Based on the scientific and professional experience, the experience of practical coaching/volunteering in international and nongovernmental organizations involved in combating human trafficking and studying scientific and pedagogical literature on this issue, members of the research laboratory "Creative Pedagogy and Public Relations" of Khmelnytskyi National University developed a questionnaire of 2 blocks and 10 questions for polygon research. And Block I contains general questions (1-5) about human trafficking; Block II contains questions (6-10) of a specific nature one's own attitude to new challenges to the problem of combating human trafficking. Its content was discussed and approved with colleagues from higher education institutions partners who were involved in the study. In addition to teachers of higher education institutions, master's degree students majoring in "Social Work", "Law", "Law Enforcement", "Psychology" were involved in the implementation of the polygon research.

We conducted the polygon research through direct surveys and questionnaires and through social networks and messengers, in compliance with the mandatory condition of voluntary confidentiality and personal data of its participants. The study involved men and women aged 18-60 + years (different professions and types of employment) - residents of cities and rural areas of the mentioned regions of Ukraine. The study covered 2,836 people, but 17 people refused at different stages of the survey (because voluntary consent was a prerequisite), and thus 2,819 people took part in the pure study; 1353 men and 1466 women.

For the mathematical validity of the results of the polygon research according to the answers of the respondents, we formed five study groups in close proximity to each other and proportionality by age and sex (men and women):

Group I - 18-29 years old (568 people); II groups - 30-39 years old (564 people); Group III - 40- 
49 years old (566 people); IV group - 50-59 years old (562 people); Group V - 60+ years old (559 people).

Processing of research results was carried out by crediting positive answers by using methods of quantitative and qualitative analysis of experimental data, graphical and comparative methods. This made it possible to analyze and present the results of the polygon study from different points of view.

\section{Results and Discussion}

The generalized results of the research are presented in percentage (\%) according to each of the questions of the questionnaire and the division by age groups and the article of the respondents in Table 1.

Table 1.

Generalized results of the polygon research*

\begin{tabular}{|c|c|c|c|c|c|c|c|c|c|c|}
\hline \multirow{3}{*}{ Question № } & \multicolumn{10}{|c|}{ Distribution by age groups and gender of respondents (in \% value) } \\
\hline & \multicolumn{2}{|c|}{$\begin{array}{l}\text { Group I } \\
(18-29)\end{array}$} & \multicolumn{2}{|c|}{$\begin{array}{l}\text { Group II } \\
(30-39)\end{array}$} & \multicolumn{2}{|c|}{$\begin{array}{l}\text { Group III } \\
(40-49)\end{array}$} & \multicolumn{2}{|c|}{$\begin{array}{l}\text { Group IV } \\
(50-59)\end{array}$} & \multicolumn{2}{|c|}{$\begin{array}{l}\text { Group V } \\
(60+)\end{array}$} \\
\hline & M & $\mathrm{F}$ & $\mathrm{M}$ & $\mathrm{F}$ & M & $\mathrm{F}$ & M & $\mathrm{F}$ & $\mathrm{M}$ & $\mathrm{F}$ \\
\hline $\begin{array}{l}\text { Do you know anything about the } \\
\text { problem of human trafficking? }\end{array}$ & 100 & 100 & 100 & 100 & 100 & 100 & 98 & 100 & 97 & 99 \\
\hline $\begin{array}{l}\text { In your opinion, is the problem of } \\
\text { human trafficking relevant for } \\
\text { Ukraine? }\end{array}$ & 98 & 99 & 97 & 100 & 95 & 96 & 94 & 97 & 95 & 89 \\
\hline $\begin{array}{l}\text { What ways to get into the situation of } \\
\text { human trafficking do you know? }\end{array}$ & 100 & 100 & 98 & 97 & 89 & 88 & 87 & 81 & 73 & 61 \\
\hline $\begin{array}{l}\text { Do you know: there is a criminal } \\
\text { liability for human trafficking in } \\
\text { Ukraine? }\end{array}$ & 99 & 97 & 82 & 80 & 84 & 87 & 62 & 64 & 53 & 49 \\
\hline $\begin{array}{l}\text { Do you think that the person should be } \\
\text { responsible for his life, actions, deeds? }\end{array}$ & 100 & 100 & 100 & 99 & 100 & 97 & 98 & 92 & 78 & 64 \\
\hline $\begin{array}{l}\text { Would you agree to employment / } \\
\text { earnings through illegal } \\
\text { intermediaries? }\end{array}$ & 100 & 95 & 96 & 90 & 98 & 82 & 95 & 98 & 97 & 98 \\
\hline $\begin{array}{l}\text { Would you agree to sell your biological } \\
\text { material / organ to make money? }\end{array}$ & 32 & 27 & 41 & 39 & 48 & 13 & 9 & 13 & 5 & 2 \\
\hline Do you see extortion and blackmail as & & & & & & & & & & \\
\hline $\begin{array}{l}\text { ways to get into a situation of human } \\
\text { trafficking? }\end{array}$ & 3 & 6 & 7 & 4 & 14 & 11 & 5 & 2 & 3 & 2 \\
\hline $\begin{array}{l}\text { Is it possible to get into a trafficking } \\
\text { situation via the Internet and social } \\
\text { networks? }\end{array}$ & 27 & 43 & 54 & 61 & 42 & 56 & 31 & 39 & 21 & 23 \\
\hline $\begin{array}{l}\text { Would you agree to participate in a } \\
\text { reproductive program? }\end{array}$ & 4 & 28 & 17 & 49 & 34 & 38 & 12 & 7 & 0 & 2 \\
\hline
\end{tabular}

*The following table showing the results of the survey was developed by the authors.

We present a detailed analysis of the results of the polygon study. The results of answers to the question №1 "Do you know anything about the problem of human trafficking?" showed a fairly high awareness of this concept $-100 \%$ in the vast majority of groups of respondents, arguing that human trafficking is a violation of human rights. The age group $(60+)$ showed approximate figures: men $97 \%$ and women $99 \%$, as well as men in the group (50-59) - a rate of $98 \%$ gave a positive answer, linking it mainly with the slave trade of Ancient Egypt and Rome.

To question №2: “In your opinion, is the problem of human trafficking relevant for Ukraine?" in almost all groups the percentage is from $94 \%$ to $100 \%$; respondents gave a positive answer. It is slightly lower in women of group V $-89 \%$. Respondents explain their positive answers by political and economic transformations in Ukraine.

To question №3: "What ways to get in the situation of human trafficking do you know?" approximate indicators in groups I-II from $100 \%$ to $97 \%$; in group III and men of group IV -89 $87 \%$. The indicators of women of group IV $81 \%$ and group $\mathrm{V}-61 \%$ in the equation and men of group $\mathrm{V}-73 \%$ are lower. The vast majority of respondents named sex services, marriage and seasonal employment abroad. It is interesting that the respondents of groups I and II named social networks as a way to get into the situation of human trafficking. This is due to the fact that the 


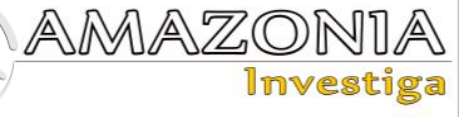

respondents of these groups are young people, and therefore gained some knowledge about the problem while studying in educational institutions.

To the question №4: "Do you know: there is a criminal liability for human trafficking in Ukraine?" the highest percentage of positive responses is in group I - 99-97\%, respectively; the answers of the surveyed groups II-III are approximately proportional $-87-82 \%$. This is due to the fact that the respondents of these groups are young people, and therefore gained some legal knowledge about the problem while studying in educational institutions. Significantly lower are the indicators of group IV - 64-62\% and especially group V - 53-49\%. Respondents from these groups reported a lack of knowledge about criminal liability for human trafficking in their own country.

To the question №5: "Do you think that a person should be responsible for his life, actions, deeds?" The respondents of groups I-IV gave positive answers, which testify to high indicators $-92-100 \%$, as most of them were born and live in Independent Ukraine. However, respondents in group $\mathrm{V}$, men $-78 \%$ and especially women $64 \%$ link responsibility for their lives, actions, deeds with the state as a constitutional guarantor of their right to life. Such circumstances can also be explained by the fact that the respondents of the $\mathrm{V}$ group aged $60+$, and therefore, lived during the Soviet Union and have certain legal and mental stereotypes about responsibility for their lives, actions and deeds.

To question №6: "Would you agree to employment / earnings through illegal intermediaries?" mostly all respondents of groups I-V answered positively - 95-100\%, slightly different indicators in women of group III $-82 \%$. High rates of positive responses in groups IV and V participants comment on the difficulty of finding a job in Ukraine after the age of 50 and low pensions. In general, respondents explain the positive answers by lack of money and the need to support the family.

To question №7: "Would you agree to sell your biological material/organ to make money?" the lowest rates of positive responses in respondents of group $\mathrm{V}-2-5 \%$ and men of group IV - 9\%; this is due to the biological age of the study participants. Somewhat different indicators were found in women of III and IV groups $-13 \%$. The rates of positive responses in the surveyed groups I $-32 \%$ and $27 \%$, II $-41 \%$ and $39 \%$ and men III $-48 \%$ are quite high and indicate extreme risks

and unreasonable considerations of the young, healthy population of Ukraine on the consequences of selling biological material/organs, especially in the legal field and in terms of their health.

To question №8: "Do you consider extortion and blackmail as ways to get into a situation of human trafficking?" mostly all respondents of groups I-III and V answered negatively - 2-7\%; slightly different indicators in group IV - 11$14 \%$. Such circumstances prove that Ukrainians perceive extortion and blackmail as normal at the time. Respondents explained their attitude to these phenomena by the high level of corruption in Ukraine, sometimes commenting on the examples of other countries.

To question №9: “Is it possible to get into a situation of human trafficking through the Internet and social networks?" almost similar are the positive responses of respondents of group $\mathrm{V}$ $-21-23 \%$. The indicators in group IV are approximate $-31 \%$ and $39 \%$. The answers of men and women in group I $-27 \%$ and $43 \%$, group II $-54 \%$ and $61 \%$, group III $-42 \%$ and $56 \%$, respectively. However, in all groups, women's responses indicate that they see the risks of being trafficked more than men through the Internet and social networks.

To question №10: "Would you agree to participate in the reproductive program?" the lowest rates of positive responses in men of group I $-4 \%$, in group IV $-12 \%$ and $7 \%$, respectively, in group $\mathrm{V}-0 \%$ and $2 \%$, respectively. The latter is explained by the biological age and socio-mental characteristics of the respondents. Group I women $-28 \%$, Group II men $-17 \%$, Group III men and women $-34 \%$ and $38 \%$ respectively gave positive answers, explaining it by the opportunity to earn. The same answers were given by women of group II $-49 \%$, whose rate is the highest. However, none of the participants linked their participation in the reproductive program to the possibility of being involved in illegal schemes, trafficking or health risks.

The generalized results of the first block $-1-3$ questions showed that the respondents generally know about the problem of human trafficking, consider it relevant for Ukraine and know about the traditional ways of getting into the situation of human trafficking mainly through media coverage (news, talk shows, PSAs). The results of questions 4-5 indicate a lack of preventive work among the population by the state: respondents mostly show superficial knowledge 
of general criminal liability, but do not have practical knowledge about it and their own responsibility.

The answers to questions 6-10 of the second block are worrying and indicate a practical lack of knowledge and understanding of their own attitude to new challenges in the fight against human trafficking. By positive answers to 6-7, 10 questions respondents explain the difficult economic situation in Ukraine, unemployment, low wages, high utility tariffs, the need to pay for housing repairs, children's education and others. The answers to questions 8-9 indicate the lack of a formed vision of the respondents on the ways to get into the situation of human trafficking at present. It should be noted that detailed answers to block II questions could be given by only $12 \%$ of respondents in all groups.

In general, the survey allowed us to implement 2 objectives of our study and based on the data of the polygon research to outline new challenges in combating trafficking in human beings in Ukraine, namely: use for selfish purposes: forced donation, trade in biological/genetic material, reproductive programs/surrogacy. We should consider them in more detail.

Forced donation. Article 144 of the Criminal Code of Ukraine defines forced donation only as the taking of blood from a person / minor for the purpose of using it as a donor. In the context of human trafficking, followed by forcible blood donation, this is covered by Part 3 of Article 149 of the Criminal Code of Ukraine "Violation of the procedure established by law for transplantation of human anatomical materials". It is important to note that violence can be physical/mental or threatening to use it. Over time, the "black market" of human organs is developing quite successfully thanks to modern gadgets, the Internet and social networks, which make it possible to track potential jokes in real time. Note that Part 5 of Article 143 of the Criminal Code of Ukraine defines the essence and content of the activities of transnational organizations that are systematically engaged in the illegal removal of the organs/tissues from people and the international illegal trade in organs/tissues of living or dead people.

Trade in biological/genetic material. The legal field of the concept of "trade in genetic/biological material" in Ukrainian legislation is virtually absent. The everincreasing number of private medical centers, especially those related to reproductive technologies, is contributing to the increase of illicit acts, in the context of trade in genetic/biological material by sex. It should be noted that such centers often do not have the appropriate license documents, and specialists do not have the appropriate level of professional training. Such circumstances are complicated by the fact that the state has virtually no control over their activities, as well as over the collection and preservation of genetic/biological material. At present, in Ukraine, the regulation of legal relations between the recipient and the donor of biological material also requires clear legislation. In the absence of a legal framework, there is virtually no official data on the consequences of violations of trade in genetic / biological material. In Ukraine, there are ongoing discussions on the creation of a national database (bank) of genetic information to establish the genetic profile of a biological object, however, in the absence of clear legislation and state control, there may be criminal schemes. It should be emphasized that trade in biological/genetic material is actively implemented in the field of reproductive programs, especially - surrogacy.

According to the results of polygon research, the young population of Ukraine in order to improve their financial situation may find themselves in a situation of human trafficking in the context of the sale of genetic/biological material/organs.

Reproductive programs/surrogacy. From a medical perspective, reproductive programs/surrogacy are linked to assisted reproductive technologies and allow people who cannot give birth naturally to become genetic parents.

If reproductive programs are generally supported by world practice, surrogacy is not clear. Some countries support this type of assisted reproductive technology, others - prohibit or have no legal regulation. In Ukraine, gestational surrogacy is allowed at the legislative level: certain provisions are mentioned by the Civil Code of Ukraine and the Family Code of Ukraine. However, traditional surrogacy is prohibited. Although, the lack of a clear legal framework for the comprehensive legal regulation of relations and control by the state in the use of assisted reproductive, especially surrogacy, leads to situations of uncertainty and, as a consequence, legal conflicts and the field for criminal activity.

At present, in Ukraine, the information on the provision of services or the participation of women/men in reproductive programs/surrogacy for a fee is actively disseminated through the 


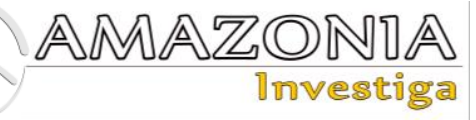

media, print advertising, the Internet and social networks. Emphasis is placed on obtaining significant profits if the customers of such services are foreign nationals of countries where it is difficult or impossible to have a child surrogate. It is noted that participation in reproductive programs/surrogacy for a fee means the conclusion of agreements involving commodity-money relations, including foreign trade. According to the current legislation of Ukraine, concluding such agreements is illegal in all cases, and in cases of surrogacy - is considered an illegal act of buying and selling a child and is recognized as child trafficking, a crime against the child.

Infertility is considered a key marker of reproductive health. However, at the moment, those who are financially secure/have achieved some career success or who have actually lost the active phase of reproductive age prefer to use the services of surrogate mothers and, in fact, buy a child. The situation is complicated when the customers of surrogacy services are foreign nationals (often members of same-sex marriages), in whose countries assisted reproductive technologies are prohibited or undefined in the legal field. In such circumstances, children may be deprived of the right of having official parents and, as a result, will not have them. There are also legal conflicts in case of force majeure, as for example, the situation with quarantine restrictions Covid-19 found that in the spring of 2020 in Ukraine in a private clinic remained more than 60 children who were ordered to Ukrainian women by foreign nationals, for a fee, with assisted reproductive technologies. Note that such agreements are aleatory, i.e. those that are concluded at the risk of proper implementation, because there are many factors in reproductive programs/surrogacy that are sometimes impossible to influence.

In general, according to experts, the market for illegal services in the field of reproductive programs/surrogacy in Ukraine has millions of shady deals and is a real platform for determining the situation of trafficking in human beings/children, and thus, it is a new challenge that requires immediate legal regulation.

\section{Conclusions}

The study allows us to state that human trafficking is recognized by the world community as a global problem. Ukraine, recognizing human rights and the rule of law as a priority, is also working to counter this negative phenomenon to ensure that those who have committed crimes are inevitably punished. The subjective aspect of crimes related to human trafficking is the presence of only direct intent, combined with the purpose of exploiting a person.

At present, in Ukraine, in addition to the traditional ones, there are new challenges in the problem of combating trafficking in human beings, which confirmed the results of the polygon study: forced donation, trafficking in biological/genetic material, reproductive programs/surrogacy. The Internet and social networks, which are an environment of cybercrime, are actively contributing to the spread of new challenges in combating human trafficking. The solution of the outlined problem is possible under the condition of legal regulation and improvement of the domestic legal base and international cooperation in the field of counteraction to transnational human trafficking.

The results of the polygon study also indicate the need for systematic and full information of the population of Ukraine on the factors, consequences, ways of getting, new challenges in combating human trafficking and legal responsibility for such criminal activity. The results obtained may be of international interest and practical value to anti-trafficking scientists, experts and professionals in various fields. We see prospects for further research in the search for and justification of effective forms, methods and means of combating trafficking in human beings in Ukraine and the development of methodological recommendations for their international implementation.

\section{Bibliographic references}

Ahtyrska, N. M., Yudenko, T. M., \& Lavrovska, I. B. (2006). Trafficking in human beings in Ukraine: as evidenced by case law. Kyiv: TOV "Company VAITE", 324 p. Retrieved from https://www.osce.org/files/f/documents/5/f/758 82.pdf

Arbeláez-Campillo, D. F., Rojas-Bahamón, M. J., \& Arbeláez-Encarnación, T. F. (2018). Notes for the debate of the categories universal citizenship, human rights and globalization. Cuestiones Políticas, 34(61), 139-161.

Danylchuk, L.O. (2018). Theory and methods of social prevention of human trafficking by means of information and communication technologies (doctoral thesis). Khmelnytskyi National University, Ternopil Volodymyr Hnatiuk National Pedagogical University, Ukraine, 561 p. Retrieved from 
http://tnpu.edu.ua/naukova-robota/docamentsdownload/d-58-053-03/Dis_Danylchuk.pdf

Dzhezhyk, O.V. (2021). Trafficking in women as a psychological, social and legal problem of society: preconditions and consequences. Habitus, vol (21), pp. 250-256. Retrieved from http://habitus.od.ua/journals/2021/212021/46.pdf

European Commission (2012). Communication from the Commission to the European Parliament, the Council, the European Economic and Social Committee and the Committee of the Regions. The EU Strategy towards the Eradication of Trafficking in Human Beings 2012-2016. Brussels, June 19. Recovered from https://op.europa.eu/en/publication-detail//publication/bc46b856-40bd-4999-8ea805d8365006c1/language-en

Faryma, M.M. (2021). Investigation of child trafficking or other illegal agreement on a child (extended abstract of candidate's thesis). National Academy of International Affairs. Kyiv, 268 p. Retrieved from http://elar.naiau.kiev.ua/jspui/bitstream/123456 789/18801/1/Дис_Фарима_ост\%20.pdf

Hodge, D.R. (2008). Sexual trafficking in the United States: A domestic problem with transnational dimensions. Social Work, 53(2), 143-152.

Hopper, E.K. (2017). Polyvictimization and developmental trauma adaptations in sex trafficked youth. Journal of Child \& Adolescent Trauma, 10(2), 161-173.

Horbasenko, P.V. (2013). General provisions of the methodology for investigating trafficking in human beings (extended abstract of candidate's thesis). Open International University of Human Development "Ukraine", Kyiv, 24 p. Retrieved

from https://dspace.nlu.edu.ua/bitstream/123456789/ 14132/1/Gorbasenko_2013.pdf

International Labour Organization (ILO). (2008). ILO Action Against Trafficking in Human Beings. Retrieved from http://www.ilo.org/wcmsp5/groups/public/@ed _norm/@declaration/documents/publication/w cms_090356.pdf

Kidane, W. (2011). Understanding human trafficking and its victims. Seattle Journal for Social Justice, 9(2), 537-548.

Kovalchuk, L.H. (2010). Socio-pedagogical conditions for the prevention of child trafficking (candidate's thesis). Instytut problem vykhovannia NAPN Ukrainy, Kyiv, 258 p.

Kravchenko, K.S. (2020). Investigation of trafficking in human beings for the purpose of labor exploitation (doctoral thesis). Taras Shevchenko National University of Kyiv, 290 p. Retrieved from http://scc.univ.kiev.ua/upload/iblock/5f0/dis_K ravchenko\%20K..pdf
Kuts, V.M., \& Orlean, A.M. (2007). Prosecutorial means of counteracting human trafficking. Kyiv: Varta, $168 \mathrm{p}$.

Law No. 1433-IV "On Ratification of the United Nations Convention against Transnational Organized Crime and the Protocols thereto". (Protocol to Prevent, Suppress and Punish Trafficking in Persons, Especially Women and Children, and the Protocol against the Illicit Import of Migrants by Land, Sea and Air). Statements of Verkhovna Rada of Ukraine, Kyiv, Ukraine, February 4, 2004, № 19. Retrieved from https://zakon.rada.gov.ua/laws/show/143315\#Text

Law No. 2539-VIII "On Amendments to Article 149 of the Criminal Code of Ukraine on Alignment with International Standards". Statements of Verkhovna Rada of Ukraine, Kyiv, Ukraine, September 6, 2018. № 41. Recovered from https://zakon.rada.gov.ua/laws/show/253919\#Text

Law No. 3739-VI "On Combating Trafficking in Human Beings". Statements of Verkhovna Rada of Ukraine, Kyiv, Ukraine, April 13, 2012, No. 19-20. Retrieved from https://zakon.rada.gov.ua/laws/show/373917\#Text

Lesko, N.V. (2019). Administrative and legal support for the formation and implementation of state policy in the field of protection of children from violence and other illegal actions (doctoral thesis). Lviv Polytechnic National University, Lviv, 489 p. Retrieved from https://lpnu.ua/sites/default/files/2020/dissertat ion/1696/dysertaciyanazdobuttyanaukovogostu penyadoktorayurydychnyhnaukleskonataliyivo lodymyrivny.pdf

Levchenko, K.B., \& Trubavina, I.M. (Eds.). (2007). Social prevention of human trafficking: tutorial (second edition). Kyiv: LLC Agency "Ukraine", $352 \mathrm{p}$.

Lukach, N.M. (2016). Conceptual principles and institutional mechanisms for counteracting the global problem of human trafficking (extended abstract of candidate's thesis). Yuriy Fedkovych Chernivtsi National University, Chernivtsi, 22 p. Retrieved from http://www.chnu.edu.ua/res/chnu/chnu_news/2 5.01.2016/aref_LUKACH.pdf

Lyzohub, Ya.H. (2003). Criminal liability for trafficking in human beings or other illegal transfer agreement: comparative and legal research. (Extended abstract of candidates's thesis). Taras Shevchenko National University of Kyiv, Kyiv, $\quad 15$ p. Retrieved from http://dspace.univd.edu.ua/xmlui/bitstream/han dle/123456789/5143/aref_Lyzohub_2003.pdf? sequence $=1 \&$ is Allowed $=\mathrm{y}$

McClain, N. M., \& Garrity, S. E. (2011). Sex trafficking and the exploitation of adolescents. 


\section{AMA}

Journal of Obstetric, Gynecologic \& Neonatal Nursing, 40(2), 243-252.

Mruchkovska, E., Pakhomiuk, N., \& Kocherha, O. (2017). Combating human trafficking in Ukraine: a training manual for special courses. Levkivskyi, K. and others (Ed.). Kyiv: WAITE, $\quad 88$ p. Retrieved from https://ippo.kubg.edu.ua/wpcontent/uploads/2017/11/Posibnyk-CTHBfinal.pdf

Panigabutra-Roberts, A. (2012). Human trafficking in the United States. Part I. State of the knowledge. Behavioral \& Social Sciences Librarian, 31(3), 138-151.

Pashchenko, M.O. (2020). The role of general and individual legal regulation in ensuring natural human rights (doctoral thesis). Taras Shevchenko National University of Kyiv, 256 p. Retrieved from http://scc.univ.kiev.ua/upload/iblock/138/dis_P ashchenko\%20M.O..pdf

Pidhorodynskyi, V.M. (2005). Liability for trafficking in human beings under criminal law (candidate's thesis). National University "Odesa Law Academy", Odesa, 20 p. Retrieved from

http://dspace.onua.edu.ua/handle/11300/1419?1 ocale-attribute $=\mathrm{uk}$

Punda, A.V. (2013). The main causes and preconditions of human trafficking in Ukraine. Public administration: improvement and development, Num. 12. Retrieved from http://www.dy.nayka.com.ua/?op=1\&z=668

Punda, A.V. (2014). Women trafficking as a problem of our time. Economy and state, 3, pp. 125-127. Retrieved from http://www.economy.in.ua/pdf/3_2014/31.pdf

Resolution of the Cabinet of Ministers of Ukraine No. 29 "On the National Coordinator on Combating Trafficking Human Beings". Kyiv, Ukraine, January 18, 2012. Retrieved from https://zakon.rada.gov.ua/laws/show/29-2012п\#Text

Resolution of the Cabinet of Ministers of Ukraine No. 303 "On Approval of the Regulations on the Establishment and Operation of the Unified State Register of Crimes of Trafficking in Human Beings”. Kyiv, Ukraine, April 18, 2012. Retrieved from https://zakon.rada.gov.ua/laws/show/3032012-п\#Text

Resolution of the Cabinet of Ministers of Ukraine No. 417. "On Approval of the Procedure for Establishing the Status of a Person Who Has Suffered from Human Trafficking”. Kyiv,
Ukraine, May 23, 2012. Retrieved from https://zakon.rada.gov.ua/laws/show/4172012-п\#Text

Resolution of the Cabinet of Ministers of Ukraine No. 783. "On Approval of the Procedure for Interaction of Entities Carrying Out Measures in the Field of Combating Trafficking in Human Beings". Kyiv, Ukraine, August 22, 2012. Retrieved from https://zakon.rada.gov.ua/laws/show/7832012-п\#Text

Shcherbakovska, K.O. (2012). Forensic characteristics of methods of child trafficking and their traces. Law and security. No. 14, pp. 205-208.

Shinkaruk, V.M., \& Khaydarzoda, Z.P. (2016). Criminal and legal characteristics of human trafficking and organizational bases of activity of state bodies in its prevention. Science Journal of VolSU. Jurisprudence, Vol. 15. No. 4 (33). 188-192. Retrieved from https://j.jvolsu.com/index.php/en/component/at tachments/download/1528

Sviatun, O.V. (2005) European mechanisms to combat human trafficking (extended abstract of candidate's thesis). Taras Shevchenko National University of Kyiv, Kyiv, 18 p.

Turok, V.V. (2016). Social and economic consequences and mechanisms of counteraction to human trafficking (extended abstract of candidate's thesis). Ptoukha Institute for Demography and Social Studies of the National Academy of Sciences of Ukraine, Kyiv, 24 p.

UNODC (2009). Combating Trafficking in Persons: A Handbook for Parliamentarians. Information and reference materials. Retrieved from

https://www.unodc.org/documents/middleeasta ndnorthafrica/human_trafficking_indicators/Ha ndbook_for_Parliamentarians_tafficking_in_pe rsons_English_.pdf

Yakushko, O. (2009). Human trafficking: A review for mental health professionals. International Journal for the Advancement of Counselling, 31(3), 158-167. Retrieved from https://digitalcommons.unl.edu/cgi/viewconten t.cgi?article $=1090 \&$ context $=$ edpsychpapers

Zhukovska, H.H. (2017). Interaction between authorities and the public in combating human trafficking (extended abstract of candidate's thesis). National Academy For Public Administration under The President Of Ukraine, Kyiv, 22 p. Retrieved from http://academy.gov.ua/pages/dop/137/files/2f0 0db17-8247-4d9c-8d5e-e173246169ce.pdf 